\section{Construções proverbiais justapostas: parataxe ou hipotaxe?}

Juxtaposed proverbial constructions: parataxis or hypotaxis?

Ivo da Costa do ROSÁRIO (UFF) rosario.ivo3@gmail.com

Letícia Martins Monteiro de BARROS (UFF) leticiamartins@id.uff.br

Recebido em: 18 de jan. de 2018. Aceito em: 30 de maio de 2018.
ROSÁRIO, Ivo da Costa do; BARROS,

Letícia Martins Monteiro de.

Construções proverbiais justapostas:

parataxe ou hipotaxe? Entrepalavras,

Fortaleza, v. 8, n. 2, p. 361-380, maio/ ago. 2018.

Resumo: Este artigo visa a investigar o estatuto das construções proverbiais justapostas em língua portuguesa. Nesse sentido, desconstrói a rígida separação entre subordinação e coordenação, geralmente baseada em critérios não muito bem definidos em relação à dependência/independência de orações. os provérbios analisados são extraídos de textos opinativos. A investigação é feita com base em uma abordagem sincrônica e qualitativa, fundamentada teoricamente na Linguística Funcional Centrada no Uso, partindo do princípio de que relações de sentido emergem de diferentes usos discursivos. Os continua propostos por Hopper \& Traugott (2003) e Haiman \& Thompson (1984) servem como base para postular que as construções proverbiais justapostas estão no intervalo entre a parataxe e a hipotaxe, devido ao seu grau intermediário de integração sintáticosemântica.

Palavras-chave: Linguística Funcional Centrada no Uso. Provérbios. Justaposição. 
v. 8 (2)

$361-380$

mai/ago 2018

Abstract: This article aims to investigate the statute of juxtaposed proverbial constructions in Portuguese language. In this sense, it deconstructs the rigid separation between subordination and coordination, generally based on not so well defined criteria regarding dependency/independency of clauses. The proverbs analyzed are extracted from opinion texts. The investigation is done based on a synchronic and qualitative approach, theoretically grounded on Usage-Based Functional Linguistics, concerning that relations of meaning emerge from different usages in discourse. The continua proposed by Hopper \& Traugott (2003) and Haiman \& Thompson (1984) serve as a base to postulate that the juxtaposed proverbial constructions are localized between parataxis and hypotaxis, due to their intermediate level of semantic-syntactic integration.

Keywords: Usage-Based Functional Linguistics. Proverbs. Juxtaposition.

\section{Introdução}

Ao longo de séculos, a Gramática Tradicional (doravante, GT) sempre gozou de forte prestígio. Sua tentativa de uniformizar o uso da língua por meio do estabelecimento de regras, de fato, ainda hoje se faz presente nas gramáticas prescritivas produzidas pelo mercado editorial brasileiro e internacional. De forma bem geral, a GT propõe normas e classificações rígidas com base em exemplos extraídos de obras literárias de séculos passados.

Os estudos mais modernos sobre conexão de orações, entretanto, têm recebido importância gradativa e crescente no âmbito dos estudos linguísticos. Novas correntes teóricas têm se debruçado sobre essa seara e têm proposto diferentes caminhos para a descrição e a análise da coordenação e da subordinação, fora do binarismo clássico.

A Linguística Funcional Centrada no Uso (doravante, LFCU) ou Abordagem Construcional da Gramática (cf. ROSÁRIO; OLIVEIRA, 2016) insere-se nesse grupo de novas teorias. A LFCU reúne pressupostos teóricos advindos do Funcionalismo de vertente norte-americana (denominado Funcionalismo Clássico) com os postulados da Gramática de Construções, especialmente na linha da Linguística Cognitiva.

A LFCU, assim como outros ramos funcionalistas, revela o caráter heterogêneo e dinâmico da língua em uso e a importância do contexto discursivo e das questões pragmáticas para a análise linguística. Seguindo essa perspectiva, a análise é sempre de forma contextualizada, calcada em dados reais.

Com base na LFCU, pretendemos, neste trabalho, desconstruir a separação rígida entre coordenação e subordinação proposta pelas gramáticas normativas e abordagens formais em geral, inserindo a noção de gradiência (cf. BYBEE, 2010) na discussão. O nosso foco são 
as construções proverbiais justapostas, levando em consideração não apenas a forma ou o sentido, mas a combinação de ambos.

Provérbios são, geralmente, estruturas fixas, convencionalizadas, fruto da cultura oral de um povo. Sua utilização, entre várias funções, visa a dar um aviso, um conselho, um ensinamento ou a fazer uma reflexão sobre algum fato cotidiano. Nada impede, no entanto, que essas estruturas sofram alterações em seus sintagmas, para que se atenda a propósitos comunicativos diversos. Assim, vejamos:

Em termos de função comunicativa, o provérbio é cheio de significados, apresenta expressões bem formadas que se estruturam em frases curtas, de estrutura binária, permitindo que estes se gravem facilmente na memória e sejam repetidos nas diversas situações interativas de uma comunidade (DIAS, 2009, p. 64).

Provavelmente, com o objetivo de facilitar sua memorização, há economia de vocábulos na construção dos provérbios e até mesmo alguns truncamentos. Isso explicaria a ausência de conjunções em sua estrutura - o que, no entanto, não impede sua compreensão, já que no momento em que são utilizados, encontram-se fundamentados no contexto discursivo.

Ao analisarmos provérbios (juntamente com os textos na íntegra), neste trabalho pretendemos mostrar os sentidos que emergem das construções proverbiais justapostas e, assim, indicar sua posição no continuum proposto por Hopper e Traugott (2003), com o auxílio das propriedades formais sugeridas por Haiman e Thompson (1984 apud ABREU, 1997). Trata-se de duas propostas complementares, visto que focalizam a integração de orações (e construções aparentadas) a partir de diferentes pontos de vista no plano funcional, como ficará mais evidente a seguir, na seção de fundamentação teórica e análise de dados. Hopper e Traugott (2003) privilegiam o aspecto funcional, ao passo que Haiman e Thompson (1984 apud ABREU, 1997) focalizam o aspecto formal.

Nesta pesquisa, entendemos como construções proverbiais justapostas estruturas como a seguinte: "Quem não tem cão caça com gato". Em uma abordagem estritamente tradicional, a oração "Quem não tem cão" é entendida por muitos gramáticos como substantiva subjetiva e, portanto, dentro do escopo da outra oração com a qual se liga. Reconhecemos o papel de sujeito desempenhado por essa oração, mas atentamos para outro aspecto da questão: a ausência de conjunção entre uma parte ("Quem não tem cão") e outra ("caça com gato") da construção. 
v. 8 (2)

$361-380$

mai/ago 2018

Nessas construções, de fato, não há nem presença de conjunção integrante (que sinaliza as orações substantivas desenvolvidas) nem formas nominais do verbo (que indicam o estatuto das orações reduzidas). Mesmo em obras tradicionais, haja vista Kury (2003, p. 72), há respaldo para considerar essas estruturas como destituídas de conectivo. De fato, o quem é um pronome ou advérbio interrogativo, e não uma conjunção. Assim, defendemos que essas estruturas enquadram-se não no rol das completivas, mas no grupo das construções justapostas, que serão mais bem delineadas ao longo deste artigo.

Da mesma forma como a correlação (ROSÁRIO, 2012; 2013; 2017), a justaposição também tem sido muito pouco abordada pela literatura gramatical. O laconismo e até mesmo o silêncio absoluto têm marcado esse conteúdo nas páginas dos compêndios dedicados ao estudo da conexão de orações. Logo, justificamos a premência desse estudo, tendo em vista a produtividade das construções justapostas em língua portuguesa.

Este artigo está dividido em cinco partes. Após essas considerações iniciais, partimos para a próxima seção, que versará sobre a clássica dicotomia coordenação vs. subordinação. Na terceira parte do artigo, exploramos como a LFCU categoriza as orações no âmbito da integração de cláusulas. Após essa seção, chegamos à questão central deste trabalho, que visa a discutir se as construções proverbiais justapostas são casos de parataxe ou hipotaxe. Por fim, apresentamos as considerações finais e referências bibliográficas.

\section{Dicotomia coordenação vs. subordinação}

A Nomenclatura Gramatical Brasileira (NGB) é um documento que simplifica e prevê a uniformização das classificações das categorias gramaticais do português do Brasil (PB), em uma perspectiva fortemente estruturalista/normativista. Segundo a NGB, no que tange à análise sintática, a orações devem ser classificadas da seguinte forma:

\footnotetext{
Classificação das orações: a) absoluta; b) principal; c) coordenada: assindética; sindética: aditiva, adversativa, alternativa, conclusiva, explicativa; d) subordinada; substantiva: subjetiva, objetiva (direta e indireta), completivanominal, apositiva, predicativa; consecutiva, concessiva, condicional, conformativa, final, proporcional e temporal (NGB, determinada pela portaria $\mathrm{n}^{0} 152$, de 24 de abril de 1957)1.
}

${ }^{1}$ Disponível em: $<$ http://www.portaldalinguaportuguesa.org/?action=ngbras $>$. Acesso em: 02 ago 2018. 
Aparentemente, a elegância da apresentação parece isenta de problemas. Entretanto, há muita divergência entre os gramáticos no que diz respeito à determinação do que seria coordenação e subordinação. Basicamente, os autores normativistas estabelecem o critério da (in) dependência: coordenadas seriam as orações independentes em relação à oração assindética (que não possui conectivo²), ao passo que as subordinadas pressuporiam dependência em relação à oração principal (cf. ROSÁRIO, 2016). Vale ressaltar, contudo, que não há unanimidade sobre o tipo de (in)dependência adotado: se sintático, semântico ou ambos.

Como muitas distinções feitas a propósito dos fatos da língua, [...] subordinação e coordenação não correspondem sempre a conceitos claros e inconfundíveis. Tradicionalmente, é comum identificar unidades coordenadas com unidades independentes e unidades subordinadas com unidades dependentes. Esta identificação nada esclarece até que se defina a natureza dessa dependência, que para uns é puramente sintática, mas para outros deve dizer respeito antes ao sentido (AZEREDO, 2013, p. 53).

Luft (2002) indica que o período composto, conforme a natureza de suas orações, pode ser por coordenação - "apenas com orações independentes - ou por subordinação - com oração principal e oração(ões) subordinada(s)". Além de não estabelecer o critério para a (in) dependência, reforça a dicotomia coordenação/subordinação, que, segundo ele, "são dois processos de estruturação sintática: dois elementos lado a lado/um elemento anexado ao outro, dependente dele. Parataxe/Hipotaxe ${ }^{3}$ - numa nomenclatura de origem grega" (LUFT, 2002, p. 70).

Embora discorde da proposta de se adicionar os processos de justaposição e correlação à classificação das orações, afirmando que não há motivos para classificá-las como "processos especiais de composição do período" (LUFT, 2002, p. 71), o autor afirma:

Alguns autores apresentam dois outros processos [além dos de coordenação e subordinação]: correlação e justaposição, somando quatro processos de estruturação sintática. Assim, orações correlatas: (a) aditivas (não só... mas também); (b) comparativas (tal... tal/mais/menos... (do) que); (c) consecutivas (tanto/tão/tal...que); - orações justapostas: (a) intercaladas (...disse ele - ); (b) apositivas; (c) objetivas diretas; (d) adverbiais (LUFT, 2002, p. 70, grifos do autor).

\footnotetext{
${ }^{2}$ Neste trabalho, optou-se por utilizar os termos conjunção e conectivo de forma intercambiável.

${ }^{3}$ Autores normativistas como Luft e Bechara usam os termos parataxe e hipotaxe como sinônimos de coordenação e subordinação, respectivamente. Essa terminologia é encarada de forma diferente por alguns autores funcionalistas, como será mostrado ao longo deste trabalho.
} 
v. $8(2)$

$361-380$

mai/ago 2018

Bechara (2009), ao contrário de Luft (2002), define o caráter de (in)dependência que norteia a classificação de orações como sendo sintático. Segundo ele, para que haja subordinação, uma oração, anteriormente independente do ponto de vista sintático, passa a uma camada inferior, funcionando "como pertença, como membro sintático de outra unidade" (BECHARA, 2009, p. 462, grifo nosso), ou seja, em uma relação desnivelada, uma oração passa a estabelecer função sintática dentro de outra, a principal. Em relação às coordenadas, Bechara (2009) explica que, diferentemente das subordinadas, são orações "sintaticamente independentes" com enunciados pertencentes a uma mesma "camada gramatical" (BECHARA, 2009, p. 463, grifo nosso).

Em relação ao processo de justaposição, também chamado de assindetismo, Bechara (2009, p. 479) explica que as orações:

podem encadear-se [...] sem que venham entrelaçadas por unidades especiais; basta-lhes apenas a sequência, em geral proferidas com contorno melódico descendente e com pausa demarcadora, assinalada sempre na escrita [...].

Vale ressaltar que o gramático entende coordenação e justaposição como processos diferentes, ainda que próximos devido à "independência sintática e o estreito relacionamento semântico" de ambos:

Aproximam-se as orações justapostas das coordenadas, e com elas às vezes se alternam, por permitirem, no nível da camada superior do texto, um sentido subsidiário de causa-explicação, concessão, consequência, oposição, tempo, levando-se em conta o conteúdo de pensamento nelas designado (BECHARA, 2009, p. 479).

Um dos aspectos segundo os quais Azeredo (2013) diverge de Luft (2002) e Bechara (2009) é o foco usado como referência para a definição de coordenação e subordinação. Em vez da (in)dependência proposta tradicionalmente, o linguista sugere que a diferença se encontra na equivalência ou não de nível entre as unidades relacionadas. Sobre a coordenação, Azeredo afirma que os elementos ligados (vocábulos, sintagmas, orações, parágrafos etc.) estabelecem uma relação discursiva em um mesmo nível, uma vez que possuem a mesma natureza ou função. Já na subordinação, um elemento se apresenta sob domínio de outro em uma relação intraoracional, apresentando, portanto, níveis distintos. Em resumo, para o autor, 
Enquanto conceito gramatical, a distinção entre coordenação e subordinação tem fundamento formal/funcional, que inclui a posição hierárquica das unidades associadas e o lugar dos instrumentos de associação: incorporado ao segmento subordinado - no qual funciona como transpositor - ou interposto aos segmentos associados, situação típica dos coordenantes (AZEREDO, 2013, p. 54).

Azeredo (2013, p. 127) faz menção ao processo de justaposição como parte da coordenação: ele usa o termo coordenação assindética para se referir às orações justapostas e entende que elas podem exprimir contraste, causa/efeito, adição ou ter a segunda oração justificando o conteúdo da primeira.

Seria possível classificar os provérbios - geralmente compostos por justaposição de orações - como estruturas de coordenação assindética? Quanto à forma, em certo sentido, os provérbios aproximam-se da coordenação. Por outro lado, com relação às relações semânticas, não. Afinal, se a contraparte do significado for levada em consideração, as construções justapostas não se encaixariam nos exemplos de coordenação, já que esta comumente não exibe relações circunstanciais tradicionalmente ligadas à subordinação. É necessário, portanto, propor uma abordagem mais adequada para as construções justapostas, que considere tanto o plano formal quanto o funcional. Vejamos como a LFCU analisa a conexão de orações em geral.

\section{A LFCU e a classificação de orações}

A LFCU, ao contrário das vertentes formalistas, não concebe a língua como uma estrutura autônoma: não faz separação rígida entre língua e fala, nem exclui de sua análise as influências externas à própria estrutura linguística. Difere-se das demais correntes teóricas, portanto,

[...] primeiro por conceber a linguagem como um instrumento de interação social e segundo porque seu interesse de investigação linguística vai além da estrutura gramatical, buscando no contexto discursivo a motivação para os fatos da língua (CUNHA; COSTA; CEZARIO, 2015, p. 21).

Sob a ótica da LFCU, a dicotomia coordenação/subordinação não é suficiente para explicar as estruturas de período complexo que emergem da interação comunicativa, já que estas envolvem, além da forma, relações semântico-pragmáticas que não condizem com a classificação restrita e dicotômica apresentada por gramáticos e outros autores tradicionalistas. Há de se estabelecer, portanto, um continuum, 
v. 8 (2)

$361-380$

mai/ago 2018

isto é, uma escala de gradiência capaz de englobar a maior parte dos casos encontrados na língua em uso. Partindo dessa ideia, Hopper e Traugott (2003) estabelecem três pontos essenciais de um cline $e^{4}$ : partese da parataxe, tendo a hipotaxe como processo intermediário, até a subordinação (ou encaixamento).

Embora hipotaxe e parataxe sejam termos já utilizados pelos formalistas, a compreensão é diferente na LFCU. Enquanto as abordagens tradicionais consideram tais vocábulos como sinônimos de subordinação e coordenação, respectivamente, Hopper e Traugott (2003) explicam que a parataxe está relacionada à relativa ausência de dependência e de encaixamento, ao passo que a hipotaxe apresenta relativa dependência e menos encaixamento. O último ponto desse continuum, a subordinação, por sua vez, é caracterizada pela dependência e pelo encaixamento total. Visualmente, tem-se o seguinte esquema:

\section{Esquema 1 - Continuum de Hopper e Traugott (2003)}

\begin{tabular}{|lll|}
\hline PARATAXE & HIPOTAXE \\
- dependência & + dependência & +dependência \\
- encaixamento & - encaixamento & + encaixamento \\
\hline
\end{tabular}

Fonte: Hopper e Traugott (2003, p. 170).

Segundo essa proposta, construções justapostas e coordenadas se encontram no primeiro extremo, à esquerda. As orações relativas apositivas e adverbiais da gramática tradicional são representadas pelas hipotáticas. Por fim, as orações completivas e relativas restritivas alocam-se no extremo dessa escala, à direita.

No campo das relações entre sintaxe e semântica, baseando-se em Givón (1979), Rosário (2015, p. 46) afirma que "a maior integração semântica ou pragmática acarreta também maior integração sintática. Assim, a estruturação sintática estaria imbricada com a significação veiculada pelas sentenças da língua".

Considerando essa ideia, no que tange às construções proverbiais justapostas, há um impasse quanto à sua posição na escala

\footnotetext{
${ }^{4}$ Cline, além de continuum, é outro termo utilizado para se referir à escala de gradiência.
} 
de Hopper e Traugott (2003). Afinal, em termos sintáticos, a justaposição se remete à parataxe, ao passo que seu sentido, por apresentar relação circunstancial, faz com que também possa estar ligada à hipotaxe.

Ao abordar essa questão, Dias (2009) privilegia a questão semântica em detrimento da formal, uma vez que se ocupa em analisar o sentido que emerge dos provérbios de configuração justaposta, afirmando que estes podem ser parafraseados com o uso de conjunções, deixando claro seu caráter adverbial e, portanto, hipotático.

Contudo, entendemos, neste trabalho, que não se deve desconsiderar a forma original do provérbio na análise, já que a LFCU se ocupa do par forma-sentido, e não de um ou outro. Como afirma Rosário (2015, p. 42),

esse estudo das relações entre forma e significado, na verdade, tem como precursor o próprio Bolinger [...], para quem uma diferença na forma sintática sempre expressa uma diferença em termos de significado.

Neste artigo, portanto, tanto a forma quanto o sentido são fundamentais em termos analíticos. Para a análise do plano da forma, serão utilizadas algumas propriedades propostas por Haiman e Thompson (1984 apud ABREU, 1997, p. 20). São elas:

1. Identidade de sujeito (mesmo sujeito em ambas as orações);

2. Ligação entonacional5 (ausência de pausa entonacional entre as orações);

3. Uma oração no escopo da outra (uma oração com função sintática dentro da outra);

4. Ausência de iconicidade temporal (ordem intercambiável das orações).

O maior índice de presença dessas propriedades indicará maior integração, deslocando as construções do nível da parataxe para a hipotaxe. Vale frisar que, na perspectiva teórica adotada, a pertença às categorias é algo escalar e não categórico. Logo, é muito comum

\footnotetext{
${ }_{5}$ Para uma análise mais refinada dessa propriedade, sem dúvida, seria necessário o uso de equipamentos que pudessem realizar uma análise prosódica de cada construção proverbial justaposta em seu contexto de uso. Como esse tipo de aparato não foi possível, para este trabalho, foram verificadas algumas marcas que indicavam a questão da ligação entonacional. Dentre essas marcas, destacam-se: a) a própria estrutura de díade que caracteriza os provérbios; b) a presença da vírgula como marca gráfica de pausa; c) o fenômeno do anacoluto. Esses pontos serão mais bem desenvolvidos e apresentados ao longo da análise de dados.
} 
v. $8(2)$

$361-380$

mai/ago 2018 que algumas construções oracionais não estejam alocadas exatamente nos pontos indicados por Hopper e Traugott (2003), mas nos intervalos entre um ponto e outro. Isso decorre da concepção gradiente de língua adotada pelos funcionalistas em geral.

No plano do significado, observaremos os valores circunstanciais que emergem dos provérbios. Para isso, muitas vezes é necessário recorrer ao contexto (neste trabalho, o linguístico, em especial) para que se possa definir com mais precisão a relação semântica emergente, uma vez que a conjunção - responsável direta por essa definição - está ausente desses enunciados.

Em sentenças como "Casa de ferreiro, espeto de pau", por exemplo, não se sabe ao certo se a relação estabelecida é temporal (Quando a casa é de ferreiro, o espeto é de pau), condicional (Se a casa é de ferreiro, o espeto é de pau), concessiva (Embora a casa seja de ferreiro, o espeto é de pau) ou se é polissêmica por natureza. Por essa razão, o contexto em que a sentença se encontra é essencial para que o sentido seja precisamente interpretado, quer de forma unitária, quer de forma polissêmica.

\section{Procedimentos metodológicos e análise de dados}

Deixamos claro, de antemão, que a estrutura submetida à análise é a mesma para todos os provérbios selecionados: são construções complexas, relacionadas semanticamente, sem o uso de conectivos. Dentre uma variedade de estruturas proverbiais, procuramos estabelecer um recorte, a fim de se produzir uma análise mais específica. Como foi apontado nas considerações iniciais, selecionamos estruturas proverbiais do tipo "Quem não tem cão caça com gato", em que tradicionalmente há orações com valor de sujeito seguidas de suas respectivas orações matrizes.

Definido o tipo de construção cuja análise será apresentada, pesquisamos alguns provérbios mais conhecidos e selecionamos, dentre eles, os que se enquadravam na estrutura preestabelecida. Em seguida, por meio da ferramenta de pesquisa disponibilizada pelo Google, verificamos em quais situações as construções proverbiais haviam sido utilizadas. A partir daí, nós as reunimos para formar o corpus deste artigo.

Em um primeiro momento da pesquisa, coletamos um corpus considerável, com mais de vinte construções proverbiais justapostas 
distintas. Como nosso objetivo é apresentar a análise das construções a partir de seu contexto de uso (texto na íntegra), por uma questão de limitação de espaço, neste artigo, serão apresentadas as análises de apenas quatro construções tomadas aleatoriamente, a partir da ocorrência de cada uma em um texto específico. Etapas posteriores desta pesquisa englobarão mais construções proverbiais em um universo de textos mais amplos, de modo a tecermos considerações mais precisas sobre o nosso objeto de pesquisa, a partir também de uma metodologia quantitativa.

Reiteramos que este trabalho configura-se como uma pesquisa de abordagem sincrônica, de cunho qualitativo, cuja finalidade é apresentar uma análise de algumas construções proverbiais justapostas, normalmente excluídas da descrição gramatical canônica. Seguindo os postulados da LFCU, serão igualmente analisados os aspectos formais e funcionais.

Destacaremos, em negrito, palavras e expressões que auxiliam na compreensão da articulação semântica que emerge do provérbio associado ao contexto, pois defendemos que há pistas linguísticas fundamentais para uma análise mais aprofundada do nosso objeto de pesquisa.

Vejamos os textos em análise:

Texto 1:

\section{Quem espera sempre alcança... Será? ${ }^{6}$}

[...]Deus se agrada daqueles que agem, daqueles que confiam na parceria, na sociedade que fazem com Ele, 50\% cabe a mim fazer e os outros $50 \%$ Ele fará por mim! Assim que, cruzar os braços e ficar esperando que um raio caia do céu e resolva sua situação não lhe trará nenhum resultado. É aí que muitos enfraquecem, começam a dizer que Deus não as ouve, que pede e Deus não atende etc., mas Ele já ouviu todas as suas orações, só está esperando você agir os seus 50\% e então, prontamente Ele fará os 50 \% que Lhe cabe na sociedade entre vocês.

O ditado deveria ser o seguinte: Quem age e espera confiando em Deus, sempre alcança! Mas, "quem espera sempre alcança”, não dá! E você já deve ter tido muitas provas disso...

O que fará? Cruzará os braços "esperando no Senhor" ou arregaçará as mangas usando a fé inteligente? [...]

6 Fonte: http://bolsablindada.com.br/quem-espera-sempre-alcanca-sera/. Acesso em: 02 ago. 2018. 
v. $8(2)$

$361-380$

mai/ago 2018

A autora do texto acima questiona o provérbio Quem espera sempre alcança, mostrando o seu ponto de vista. Segundo ela, quando se espera que os problemas se resolvam sozinhos, nada acontece. A proposição temporal é percebida devido às escolhas de palavras e expressões utilizadas no texto, como os advérbios sempre, que indica frequência e está associado ao tempo, e prontamente, o qual transmite a ideia de instantaneidade.

O conectivo assim que, que expressa ideia similar a prontamente, também está relacionado à questão temporal. Pode-se, então, entender que a paráfrase "Quando se espera, se alcança" se aproximaria semanticamente da circunstância expressa no texto em questão. Ainda assim, é importante lembrar que, modificando a forma, alteram-se também sentido e intenção pragmáticos.

Em relação à estrutura formal do provérbio, temos identidade de sujeito (esperar e alcançar são atribuídos a um mesmo sujeito), há uma pequena pausa entonacional entre as duas partes (aferida pela estrutura de díade, típica dos provérbios), uma oração é sujeito da outra e não há iconicidade temporal. Esses traços são sumarizados a seguir:

+ identidade de sujeito

- ligação entonacional

+ uma oração no escopo da outra

+ ausência de iconicidade temporal

Vejamos agora o texto 2:

Quem com ferro fere, com ferro será ferido ${ }^{7}$

Newton foi um cientista inglês do século XVII que enunciou, dentre outras leis, a lei da Ação e Reação. Em síntese, a lei natural é enunciada da seguinte maneira: "Toda ação promove uma reação, de mesma intensidade, mesma direção, mas de sentido contrário". Se essa lei rege todos os corpos do universo e nós somos corpos do universo... (!) todas nossas ações promovem reações!

Se as pessoas estudassem um pouco mais de física, talvez não viveríamos num mundo de tanta hipocrisia. Talvez assim deixaríamos de culpar os famintos, os pedintes, os favelados e os analfabetos pela violência, pelo não crescimento econômico deste ou de qualquer outro país. Talvez

7 Fonte: http://reticenciasatitude.blogspot.com.br/2007/05/quem-com-ferro-ferecom-ferro-ser.html. Acesso em: 02 ago. 2018. 
seríamos capazes de tirar a máscara da vaidade e da "não-tenho-nada-comisso" para enxergar que a situação caótica que estamos vivendo é o fruto de um passado regido pelas desigualdades, desamparo estatal, apatia social, falta de educação, elitização do ensino e da cultura e da histórica e vergonhosa lama de corrupção que envolve nosso país desde sempre.

Ao longo do segundo texto, a autora dá pistas sobre a relação circunstancial pretendida por ela na utilização do provérbio Quem com ferro fere, com ferro será ferido. De acordo com ela, a condição hipotética para se acabar com os problemas sociais da atualidade seria reconhecer o que a sociedade fez de errado no passado e tentar consertar, já que toda ação tem uma consequência.

O uso da conjunção condicional se, atrelado à preferência pela conjugação verbal no futuro do pretérito e ao uso do advérbio de dúvida talvez, revela um plano hipotético, passível de acontecer sob algumas condições. Porém, as relações semânticas mais relevantes indicadas pelo contexto e que dizem respeito especificamente ao uso desse provérbio são de causa/efeito e temporalidade, já que a autora se refere aos acontecimentos do passado como causa das mazelas sociais do presente. De fato, isso pode ser percebido nos trechos em negrito. Destacar a relação semântica mais preponderante é desafiador, uma vez que os matizes de significado apresentam limites difusos e estão intrinsecamente associados.

Em relação à estrutura formal do provérbio, temos identidade de sujeito (o mesmo indivíduo que fere também é ferido), há uma pausa entonacional considerável entre as duas partes (demarcada, inclusive, pelo uso da vírgula), uma oração é sujeito da outra e não há iconicidade temporal. Esses traços são sumarizados a seguir:

+ identidade de sujeito

- ligação entonacional

+ uma oração no escopo da outra

+ ausência de iconicidade temporal

Agora, vejamos o texto 3: 
V. $8(2)$

$361-380$

mai/ago 2018
Quem semeia ventos... ${ }^{8}$

O título acima que não terminamos, refere-se à máxima popular de que "quem semeia ventos, colhe tempestades". Nada mais correto. Se dispensamos um carinho, uma palavra de afeto, um olhar de ternura ou um gesto de ajuda material, por menor que seja, não podemos nos queixar se tudo isso que deixamos de fazer, também a nós for negado.

Por outro lado, se maltratamos as pessoas, se as odiamos, se as invejamos, se fazemos com que elas nos inspirem rancor e repulsa, não podemos cobrar coisa diversa daquilo que semeamos, pois tendo saldo negativo na balança de nossas ações, o resgate é inevitável na medida talionária.

É a Lei da Reciprocidade, aquela que age em função da vontade Divina e não pergunta se a criatura ofensora é pobre, rica, tem alto cargo, qual a nacionalidade, se é branca ou de cor. Nem voando nas asas da aurora o ser humano escapa dessa inviolável e infalivel lei, seja aqui ou no além.

A maioria dos seremos humanos gosta de levar vantagens acerca de quase tudo. No trabalho, no lazer ou nas relações pessoais, eles adoram que as coisas lhes sejam feitas, com o mínimo esforço e menor custo financeiro possível. São os eternos egoístas, aqueles que jamais fazem algo por abnegação, por solidariedade humana, pois sempre esperam algo em troca.

Quando as coisas não correm como eles esperam, tomam as atitudes que melhor lhes caibam, independente dos sentimentos alheios, pouco importando se laços familiares os ligam àqueles que lhes deram a vida. São pessoas extremamente egocêntricas. Acham que o mundo gira em torno deles. Sentem-se como se estivessem num pedestal. Cair dele é somente uma questão de tempo.

Onossoconto ilustrativo da semanaésobrefazer aquilo quegostaríamos não fizessem a nós: "Um lenhador não tinha estudo. Muito trabalhador, cortava lenha desde o raiar do dia até o sol se pôr e vendia-a para uma cidade próxima, aplicando todo o dinheiro no estudo de seu filho, que queria ser médico.

O tempo foi passando. O menino conseguiu entrar na faculdade de medicina e tornou-se um grande médico, ficando famoso e muito rico. Construiu uma linda casa, casou-se e teve um filho. Seu pai, o lenhador, já muito velho e doente, foi morar com seu filho médico. Porém este tinha uma vida social intensa, recebia muitos amigos importantes em sua casa.

Resolveu colocar seu pai no quarto do fundo, pois, como não tinha estudo e era muito simples, não deveria estar conversando com pessoas cultas. Com o passar do tempo, as mãos do lenhador, cansadas de tanto cortar lenha, já tremiam e acabavam por quebrar as louças finas do médico.

${ }^{8}$ Fonte: http://www.paralerepensar.com.br/richard_quemsemeiaventos.htm. Acesso em: 02 ago. 2018. 
Então este fez uma gamelinha de barro para as refeições do pai e colocava-o para comer no quintal. O filho do médico gostava de fazer companhia ao avô nas horas das refeições. Um dia o médico foi ao encontro de seu filho, e este estava no quintal fazendo uma gamelinha de barro.

Então seu pai disse: - Para que isso, filho? Ao que ele respondeu: Para você comer quando ficar velho e sua mão começar a tremer como a do vovô. Moral da história: nosso presente é fruto do nosso passado. Colheremos amanhã o fruto do que estamos plantando hoje. Vamos prestar atenção no tipo de semente que estamos plantando."

O texto 3 é outro exemplo de proposição circunstancial que suscita mais de uma interpretação, visto que a relação causa/efeito está intimamente ligada à questão temporal e à condicionalidade. A consequência de "semear ventos" no presente é "colher tempestade" no futuro, o que é ilustrado pela história contada no texto por meio da atitude do personagem mais jovem de indicar que o pai teria no futuro aquilo que fez com o próprio pai.

Ao mesmo tempo, há o tom de conselho revelado não só pelo provérbio em si, mas pela escolha da conjunção condicional se ao longo do texto. Dessa forma, é possível perceber a dificuldade em desassociar tempo, condicionalidade e consequência na interpretação da circunstância estabelecida pelo provérbio.

Em relação à estrutura formal do provérbio, temos identidade de sujeito (semear e colher são atribuídos a um mesmo sujeito), há uma pequena pausa entonacional entre as duas partes (indicada pela vírgula na formulação completa do provérbio, logo no primeiro parágrafo do texto), uma oração é sujeito da outra e não há iconicidade temporal. Esses traços são sintetizados a seguir:

+ identidade de sujeito

- ligação entonacional

+ uma oração no escopo da outra

+ ausência de iconicidade temporal

Por fim, vejamos o texto 4 : 
V. 8 (2)

$361-380$

mai/ago 2018

\section{Quem ama o feio, bonito lhe parece ${ }^{9}$}

A visão romântica da vida, na sua subjetividade, dentre várias características, entende que a definição de beleza depende do ponto de vista de cada um de nós, e que o belo depende dos olhos de quem o vê.

Shakespeare e sua obra Romeu e Julieta, ressalta o amor acima de qualquer coisa. Representação de um sentimento puro everdadeiro, que embora não queiramos imaginar, a estética fica em segundo plano e não nos permite aceitar que podem não ser tão belos e maravilhosos quanto acreditamos.

E assim somos nós, na nossa realidade - amamos o feio, parecendonos bonitos - e sequer percebemos o quanto somos românticos nas nossas atitudes e sentimentos.

As relações nascem por acaso e por interesse, infelizmente, sem demora nas suas descobertas. Quando acontecem, caímos numa realidade que o tempo se encarrega de determinar o tempo de existência. Nenhuma "embalagem" consegue defender a qualidade de um produto por muito tempo, sem que seja descoberta a tempo de desfazer um encanto ou uma precipitação.

Estamos cada vez mais induzidos aos cuidados com o corpo, na busca por uma perfeição, de uma estética, que definem beleza, mas nem sempre caráter. É uma condição que parece cegar tantos, que leva a definir sem mesmo saber significados, e a desvalorizar, parecendo injusto e preconceituoso, num mundo em que um dia, que possuía uma gordurinhas a mais era sinônimo de riqueza.

Ainda encontramos o "contraditório" nas relações modernas, ou seja, alguém que apresenta o perfil de beleza moderna numa relação com o "feio" aos olhos do novo padrão de beleza que toma conta do mundo. Inevitavelmente as atenções se voltam a elas, com questionamentos mentalizados ou materializados do tipo: Como uma pessoa tão linda daquela namora alguém tão feio?

Que pena! A humanidade ainda precisa muito evoluir em todos os aspectos, inclusive, na sua concepção da definição de beleza. Parece que custará a entender que a visão romântica sobre o belo permite descobertas que podem ir além de um corpo sarado e músculos definidos.

O texto 4 critica a sociedade atual e a busca de relacionamentos baseados em questões superficiais, como a beleza exterior. A proposição circunstancial, nesse caso, é mais sutil e pode ser percebida por meio do destaque dado pelo autor à modernidade e aos padrões de estética que a

9 Fonte: http://pdelano.blogspot.com.br/2016/08/quem-ama-o-feio-bonito-lheparece.html. Acesso em: 02 ago. 2018. 
ela estão atrelados em contraste com o amor retratado por Shakespeare no século XVI. Pode-se dizer, com base na escolha lexical utilizada e no enfoque pretendido, que a relação temporal recebe destaque nesse texto.

No provérbio apresentado, não há identidade de sujeito. O sujeito da segunda parte do provérbio é "o feio" que, por sua vez, é argumento interno de "Quem ama o feio". Há ruptura da estrutura sintática em "Quem ama o feio / bonito lhe parece", o que é conhecido pela gramática normativa como anacoluto. Trata-se de uma estrutura idiossincrática, mas em uso no PB.

Ainda com relação a termos formais, há uma considerável pausa entonacional entre as duas partes (identificada pela vírgula e pelo próprio anacoluto). O termo "o feio" (presente na primeira parte do provérbio), como já foi indicado, é sujeito da oração presente na segunda parte do provérbio e, por fim, não há iconicidade temporal. Esses traços são sintetizados a seguir:

- identidade de sujeito

- ligação entonacional

+ uma oração no escopo da outra

+ ausência de iconicidade temporal

Até então, com base na análise dos provérbios supracitados, é possível perceber que todos possuem forma bastante semelhante: trata-se de orações relacionadas semanticamente, sem que estejam, no entanto, conectadas por conjunção. Ademais, as relações circunstanciais tendem a ser difusas e polissêmicas.

Em trabalhos de cunho funcionalista, em que a semântica e a pragmática são levadas em consideração, é preciso que se analisem mais profundamente as relações de sentido estabelecidas nas articulações sintáticas. Por meio da análise semântica, revela-se a proximidade das construções proverbiais justapostas com as orações hipotáticas adverbiais, justamente devido às proposições circunstanciais que emergem da relação entre os elementos que compõem os provérbios.

Assim, dentro do continuum proposto por Hopper e Traugott (2003), entendemos não ser possível considerar as construções proverbiais justapostas analisadas neste trabalho como orações subjetivas ligadas a uma matriz, no sentido mais estrito. Devido aos traços manifestados (tanto no plano da forma quanto no plano do sentido), propomos, de 
v. 8 (2)

$361-380$

mai/ago 2018

forma mais direta, que tais construções sejam alocadas entre os dois primeiros pontos do cline (entre parataxe e hipotaxe), pois se apresentam com características que a distinguem dos demais processos.

Com o auxílio das propriedades selecionadas de Haiman e Thompson (1984 apud ABREU, 1997), uma proposta de posicionamento dos provérbios analisados seria a seguinte:

Esquema 2 - Posicionamento dos provérbios analisados

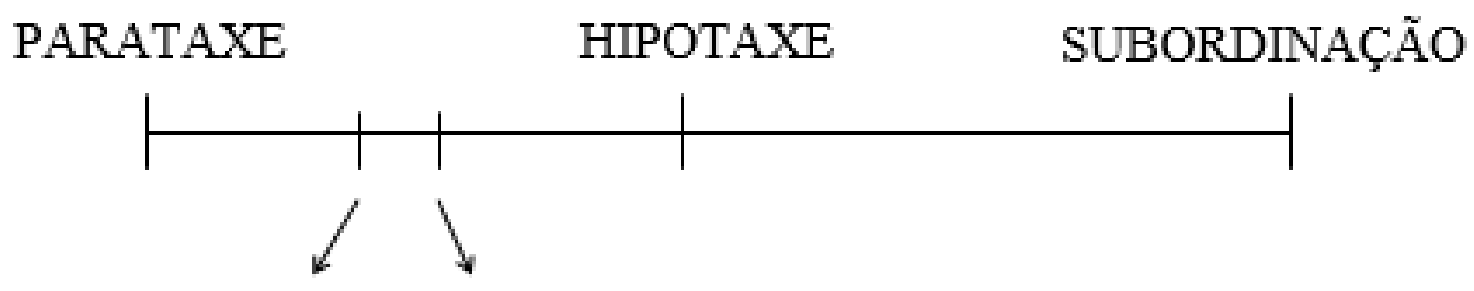

\section{Provérbio $4 \quad$ Provérbios 1,2 e 3}

Fonte: elaborado pelos autores.

Conforme podemos observar na representação esquemática anterior, os provérbios 1, 2 e 3 ocupam o mesmo lugar no continuum por apresentarem a mesma estrutura formal no que tange às propriedades propostas por Haiman e Thompson (1984): [+ identidade de sujeito]; [ligação entonacional]; [+ uma oração no escopo da outra]; [+ ausência de iconicidade temporal].

O provérbio presente no texto 4, por outro lado, revelase menos integrado, devido a [- identidade de sujeito]; [- ligação entonacional]; [+ uma oração no escopo da outra]; [+ ausência de iconicidade temporal].

Assim, é possível comprovar que as construções proverbiais justapostas são estruturas que se inserem entre a parataxe e a hipotaxe, revelando diferentes níveis de integração, a depender de suas propriedades formais.

\section{Considerações finais}

Em se tratando de classificar orações de um período composto no português do Brasil, muitos autores contemporâneos discordam da tradicional dicotomia coordenação/subordinação, que apresenta, além de indefinições sobre a natureza da (in)dependência entre elas, exemplos descontextualizados e preocupação maior com a forma em detrimento do sentido por ela expresso. 
Na LFCU, o par forma-sentido é analisado conjuntamente, buscando na interação discursiva, isto é, na língua em uso, explicações para a estrutura linguística e seus significados. Assim, a dicotomia parataxe/hipotaxe tradicional dá lugar a uma escala proposta por Hopper e Traugott (2003) em que são mensurados os diferentes graus de pertencimento à parataxe, à hipotaxe e à subordinação - termos já ressignificados pela LFCU.

As construções proverbiais justapostas analisadas neste trabalho apresentam estrutura formal similar à da parataxe, mas se aproximam semanticamente das circunstâncias expressas pelas orações hipotáticas. De acordo com os critérios aplicados nesta pesquisa, essas construções encontram-se no intervalo entre esses pontos do continuum, em graus distintos de integração. Essa perspectiva rompe com as formulações tradicionais, que sempre são categóricas.

Em síntese, este trabalho procurou lançar luzes sobre o tema da justaposição, tão pouco estudado em nossas gramáticas. Esperamos que as investigações aqui sintetizadas possam fomentar outras pesquisas em prol da descrição e análise do grande universo da integração oracional em língua portuguesa.

\section{Referências}

ABREU, António Suárez. Coordenação e Subordinação - uma proposta de descrição gramatical. Alfa. São Paulo: 1997. p. 13-37. Disponível em: <http:// seer.fclar.unesp.br/alfa/article/view/4009>. Acesso em: 18 jan. 2018.

AZEREDO, José Carlos. Iniciação à sintaxe do português. Rio de Janeiro: Jorge Zahar Editor, 2013.

BECHARA, Evanildo. Moderna gramática portuguesa. Rio de Janeiro: Nova Fronteira, 2009.

BYBEE, Joan. Language, Usage and Cognition. Cambridge: Cambridge University Press, 2010.

CUNHA, Maria Angélica Furtado da; COSTA, Marcos Antonio; CEZARIO, Maria Maura. Pressupostos teóricos fundamentais. In: CUNHA, Maria Angélica Furtado da; OLIVEIRA, Mariangela Rios de; MARTELOTTA, Mário Eduardo (orgs.). Linguística Funcional teoria e prática. São Paulo: Parábola Editorial, 2015. p. 21-47.

DIAS, Maria de Lourdes Vaz Sppezapria. A articulação hipotática em construções proverbiais justapostas. 2009. 120 f. Dissertação (Mestrado em Língua Portuguesa) - Prorgrama de Pós-Graduação em Letras Vernáculas, Universidade Federal do Rio de Janeiro, 2009. Disponível em: <http://www.letras.ufrj.br/posverna/mestrado/ DiasMLVS.pdf>. Acesso em: 18 jan. 2018.

HOPPER, Paul J.; TRAUGOTT, Elizabeth Closs. Grammaticalization. Cambridge, England: Cambridge University Press, 2003. 
V. $8(2)$

$361-380$

mai/ago 2018

KURY, Adriano da Gama. Novas lições de análise sintática. São Paulo: Ática, 2003.

LUFT, Celso Pedro. Moderna Gramática Brasileira. São Paulo: Globo, 2002.

ROSÁRIO, Ivo da Costa. Construções correlatas aditivas e disjuntivas. In: Odisséia, v. Especial, p. 103-124, 2017. Disponível em: <https://periodicos.ufrn.br/odisseia/ article/view/12903/9020>. Acesso em: 18 jan. 2018.

Construções correlatas aditivas em perspectiva funcional. 2012. $239 \mathrm{f}$. Tese (Doutorado em Letras), Instituto de Letras, Universidade Federal Fluminense, Niterói-RJ, 2012. 239p.

Construções correlatas aditivas na perspectiva da Linguística Funcional Centrada no Uso. In: SEMINÁRIO INTERNACIONAL DO GRUPO DE ESTUDOS DISCURSO \& GRAMÁTICA, 4.; SEMINÁRIO NACIONAL DO GRUPO DE ESTUDOS DISCURSO \& GRAMÁTICA: TEORIA DA GRAMATICALIZAÇÃO E GRAMÁTICA DE CONSTRUÇÕES, 17, 2013, Natal. Anais... Natal: Editora da UFRN, 2013. p. 26-41. Disponível em: <https://degnatal.files.wordpress. com/2015/04/teoria-da-gramaticalizac3a7c3a3oe-gramc3a1tica-de- construc3a7c3b5es.pdf>. Acesso em: 18 jan. 2018.

- Gramática, gramaticalização, construções e integração oracional: algumas reflexões. In: OLIVEIRA, Mariangela Rios de; ROSÁRIO, Ivo da Costa do (Orgs.). Linguística Centrada no Uso - teoria e método. Rio de Janeiro: Lamparina, 2015. p. $36-50$.

Reflexões sobre o critério da (in)dependência no âmbito da integração de orações. In: Línguas \& Letras, v. 17, n. 35, Cascavel-PR, p. 252-272, 2016. Disponível em: <http://e-revista.unioeste.br/index.php/linguaseletras/article/view/12744>. Acesso em: 18 jan. 2018. 